\title{
EFFECT OF CHEMICAL COMPOSITION ON THE PERFORMANCE OF CENTRIFUGALLY CAST INDEFINITE CHILLED CAST IRON ROLLS
}

\author{
Gimaletdinov R.Kh., Gulakov A.A., Tukhvatulin I.Kh.
}

Kushva Roll Manufacturing Factory, Kushva, Russia

\begin{abstract}
Problem Statement (Relevance): An urgent task of rolling mill operators includes minimizing the cost of manufactured products while ensuring the required quality. To accomplish the task, measures are being taken to optimize the rolling process aimed at increasing the duration of the rolling campaigns and reducing the number of roll regrinds. The performance of the rolls is influenced by the properties of the working layer material which determine wear resistance, formation and development of fire cracks, as well as resistance to metal sticking. Finishing mill rolls dictate the surface quality of the rolled steel. That is why it is important to make timely regrinds in order to completely remove the fire crack layer. The removal depth and the acceptable duration of the campaigns depend on the properties of the roll working layer material. To improve the properties of the rolls, the roll manufacturers need the actual roll operation data to be able to analyze how the chemical composition and the structure of the roll working layer is related to the roll performance. Such analysis will help improve the structure and properties of the materials used, as well as develop new ones. Objectives: The objective of this research is to understand how the chemical composition of the working layer of indefinite chilled cast iron rolls used in finishing mills dictates the roll performance, to evaluate the effect of each chemical element, and to determine what concentrations of the chemical elements could most effectively benefit the performance of indefinite chilled cast iron rolls. Methods Applied: The methods applied include building a database of the finishing mill indefinite chilled cast iron rolls and using artificial neural networks based on a dual-function algorithm. Originality: The authors built a neuromodel which can help understand the effect of the chemical composition of the roll working layer and predict the performance of indefinite chilled cast iron rolls. The authors studied the effect of carbon, silicon, manganese, chromium, nickel, molybdenum, vanadium, niobium and boron on the performance of indefinite chilled cast iron rolls. Findings: Graphic diagrams were built which demonstrate the effect of each chemical element on the performance of indefinite chilled cast iron rolls at constant concentrations of the remaining elements. The authors looked at the relationship between the chemical elements and the roll performance in terms of the impact of the former on the structure of indefinite chilled cast iron rolls. The effective concentrations of the chemical elements were also determined. Practical Relevance: The authors developed a new chemical composition of indefinite chilled cast iron to be used for the working layer of finishing mill rolls. As a result, a $12-14 \%$ increase in the roll performance was achieved.
\end{abstract}

Keywords: Mill rolls, indefinite chilled cast iron, chemical composition, effect, performance, wear resistance.

\section{Introduction}

In modern conditions of rolling production, the efficiency of using mill rolls is estimated by the ratio of quality and roll prices. At rolling sites producing plate metal, performance records are being held in time per roll in tons or kilometers of rolled metal, in tons of rolled metal per $1 \mathrm{~mm}$ of working layer removal, in tons of rolled metal per installation. Comparing different manufacturers roll performances, and comparing the prices of the rolls, the distributors make up the rating of suppliers and determine the volume of orders. In a competitive environment, the manufacturers' task is to ensure high performance characteristics of the mill rolls at minimal cost. This will increase the duration of the campaigns and more efficiently use rolling rolls. One of the ways to solve this problem is to optimize the chemical composition of rolls working layer in or-

(c) Gimaletdinov R.Kh., Gulakov A.A., Tukhvatulin I.Kh., 2019 der to increase productivity.

To assess the alloying efficiency of rolls working layer, it is advisable to research the effect of each chemical element separately, at constant concentrations of the remaining elements. This will allow you to determine the rational concentration of chemical elements that will increase the productivity of rolling rolls.

\section{Main Part}

In order to study the influence of working layer chemical composition of centrifugal casted finishing stands indefinite rolls on productivity, neural network processing of a database of 85 rolls with a barrel diameter of $820 \mathrm{~mm}$ was performed. The content of chemical elements in the working layer of the rolls varies within the following limits: $3,05 \div 3,45 \% \mathrm{C}$, $0,90 \div 1,18 \% \mathrm{Si}, 0,80 \div 1,00 \% \mathrm{Mn}, 0,007 \div 0,028 \% \mathrm{~S}$, $1,70 \div 2,15 \% \mathrm{Cr}, 4,05 \div 4,60 \% \mathrm{Ni}, 0,30 \div 0,43 \% \mathrm{Mo}$, $0,02 \div 0,31 \% \mathrm{~V}, 0,01 \div 1,13 \% \mathrm{Nb}, 0,002 \div 0,090 \%$ B. 
The resulting neuromodel allows us to predict the performance of the rolls in tons of rolled steel with a relative error of up to $10 \%$. The influence of each element was researched at constant concentrations of the remaining elements and constant values of casting technological parameters. The following chemical composition was used as the base: $\mathrm{C}=3,36 \%, \quad \mathrm{Si}=1,18 \%, \quad \mathrm{Mn}=0,80 \%$, $\mathrm{S}=0,07 \%, \quad \mathrm{Cr}=1,82 \%, \quad \mathrm{Ni}=4,23 \%, \quad \mathrm{Mo}=0,30 \%$, $\mathrm{V}=0,31 \%, \mathrm{Nb}=0,65 \%, \mathrm{~B}=0,002 \%$.

Picture 1 shows the effect of carbon in the working layer on the productivity of indefinite rolls.

With an increase in carbon content to $3,20 \%$, the productivity increases from 232,000 tons to 242,400 tons (by $4,5 \%$ ), then decreases. In the indefinite cast iron of the studied composition, carbon increases the amount of cementite and special carbides of type $\mathrm{MC}$, contributing to an increase in the productivity of the rolls due to an increase in wear resistance of the working layer. A further increase in carbon content leads to the enlargement of cementite inclusions, which increases their tendency to chipping out of the matrix.

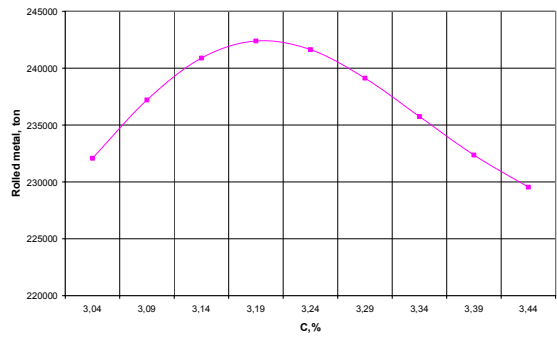

Pic. 1. The influence of carbon working layer on the indefinite rolls performance

Silicon with its content of more than $1,00 \%$ increases the productivity of the rolls by $5,0 \%$ (pic. 2). Silicon reduces the iron's tendency to oxidation and increases the resistance to wear [1,2], which has a positive effect on the performance of indefinite rolls. In [3] it is shown that, despite the graphitizing effect of silicon and a decrease in the amount of cementite, it promotes an increase in the amount of martensite in the matrix, slightly increasing the hardness at a content up to $1,20 \% \mathrm{Si}$. Reducing the amount of cementite leads to a decrease in chipping of inclusions of cementite from the matrix, and, consequently, to a decrease in wear.

Manganese, with an increase in its content to $0,95 \%$, increases productivity by $2,4 \%$ (pic. 3 ). Alloying cementite and increasing the proportion of martensite, manganese contributes to an increase in wear resistance, but because of its austenitizing effect, it is necessary to limit its content to $1,00 \%$ [3].

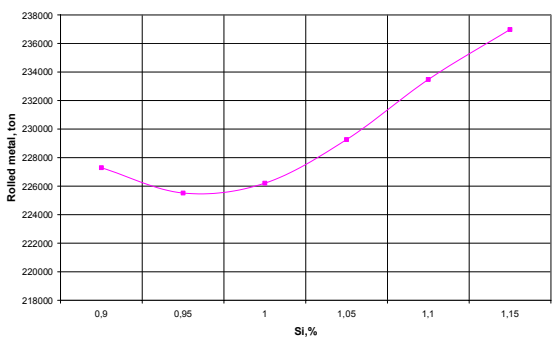

Pic. 2. The influence of silicon working layer on the indefinite rolls performance

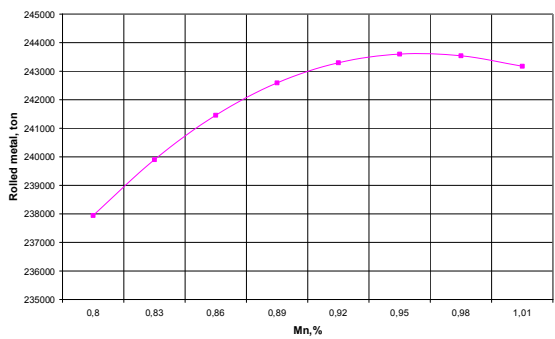

Pic. 3. The effect of manganese working layer on the indefinite rolls performance

Increasing the chromium content to $1,90 \%$ also increases the productivity of the rolls by $4,1 \%$ (pic. 4). As a strong carbide forming element, chromium increases the amount of carbides $(\mathrm{Fe}, \mathrm{Cr})_{3} \mathrm{C}$, increasing the wear resistance of indefinite cast iron. A further increase in the chromium content leads to an increase in the share of ledeburite, and, as a consequence, to a more intensive development of microcracks during the operation of the rolls [3].

Nickel in the studied interval has a weak effect on productivity, and, given the high cost of nickel, it does not make sense to increase its content by more than $4,30 \%$. Molybdenum in the entire researched interval contributes to an increase in the productivity of the rolls by $1,2 \%$ (pic. 5). Molybdenum has a beneficial effect on the indefinite cast iron matrix, increasing its dispersion, strength at high temperature, resistance to thermal cyclic loads and wear [4]. However, the economic feasibility of increasing its content above $0,40 \%$ should be evaluated.

Vanadium increases rolls productivity of the studied composition by $2,3 \%$ (pic. 6). It increases 
the dispersion of the dendritic structure, forms highly solid fine VC carbides, and increases strength and wear resistance [4].

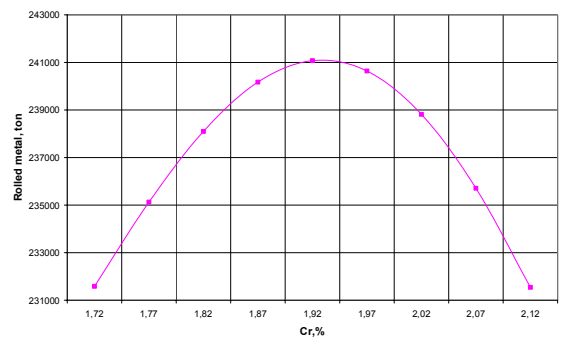

Pic. 4. The effect of chromium working layer on the indefinite rolls perfor-mance

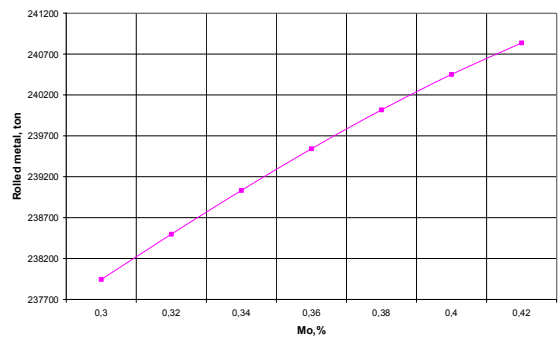

Pic. 5. The effect of molybdenum working layer on the indefinite rolls perfor-mance

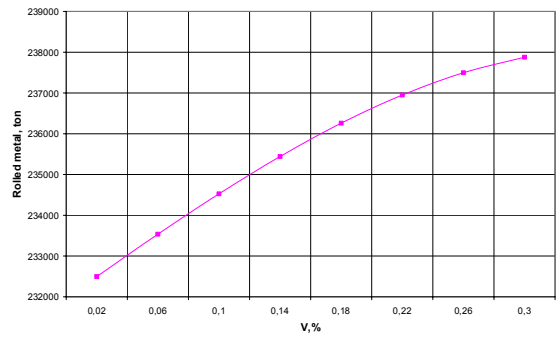

Pic. 6. The effect of vanadium working layer on the indefinite rolls perform-ance

Pic. 7 shows the effect of niobium on the performance of indefinite iron with different boron contents. Just like vanadium, it forms highly solid fine MC carbides, which have a high fracture resistance due to the compact form of the inclusions and close lattice parameters of the carbides and the matrix [5]. However, its effect amplifies with increasing boron content: at $\mathrm{B}=0,002 \%$, niobium increases rolls productivity of the studied composition by $1,6 \%$, at $\mathrm{B}=0,050 \%$, its efficiency increases - productivity also increases by $2,0 \div 2,9 \%$, and at $\mathrm{B}=0,090 \%$ - by $3,9 \div 5,0 \%$. This is due to the fact that boron forms iron boride and boron carbides, which additionally increase wear resistance [6, 7]. In the indefinite iron of the studied composition, boron increases the productivity of the rolls up to $5,0 \%$ (pic. 8). However, it should be taken into account that the abundance-boron content contributes to an increase in the share of ledeburite and to an increase in the brittleness of cast iron [8].

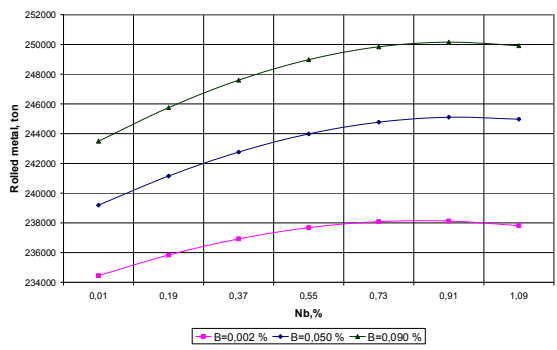

Pic.7. The effect of niobium of the working layer on the indefinite rolls perfor-mance

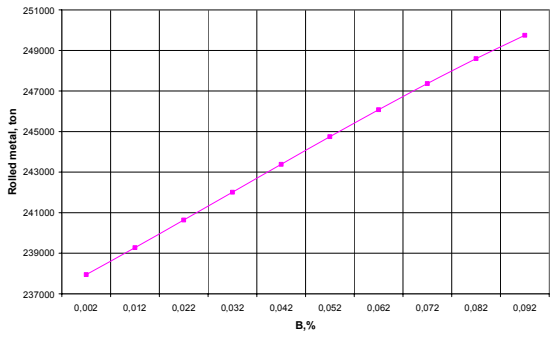

Pic. 8. The influence of boron working layer on the indefinite rolls performance

\section{Conclusion}

The conducted studies allow us to determine the rational composition of indefinite cast iron in order to increase the productivity of rolling rolls during finishing rolling.

The carbon content should be in the range of $3,15 \div 3,25 \%$. This content is sufficient for the formation of special carbides $\mathrm{MC}$, and at the same time will not lead to the consolidation of cementite inclusions.

Silicon in researched limits improves the per- 
formance of indefinite rolls, but it is necessary to take into account the graphite-forming effect of silicon [3]. Therefore, it is advisable to limit the silicon content within $1,05 \div 1,15 \%$.

To improve rolls performance, the manganese content interval of $0,90 \div 1,00 \%$ is rational.

Compared with the studies of chromium effect on the structure presented in Pic [3], in this work, the researched range of chromium content is extended to $2,15 \%$, within the optimum performance of the rolls is revealed. Research results have shown that to increase rolls productivity, chromium content should be in the range of $1,90 \div 1,95 \%$.

Considering insignificant effect of molybdenum on increasing of rolls productivity at its high cost, it is advisable to limit it within $0,30 \div 0,35 \%$.

Vanadium, forming fine VC special carbides, has a beneficial effect on the wear resistance of indefinite cast iron. The recommended vanadium content is $0,25 \div 0,30 \%$

Niobium, like vanadium, forms fine special $\mathrm{NbC}$ carbides, which increase wear resistance. However, its reasonable concentration depends on the boron content: in the absence of boron, the rational range of alloying with niobium is $0,60 \div 0,70 \%$, and when alloying of cast iron is $0,050 \div 0,090 \% \mathrm{~B}$, the rational niobium content is higher $-0,80 \div 0,90 \%$.

Boron has a significant positive effect on rolls productivity in the researched range of its content. The linear character of boron effect (pic. 8) allows you to select the maximum concentration of boron in this interval $-0,080 \div 0,090 \%$.

According to the results of research carried out in this work, a new chemical composition of indefinite cast iron was developed for the rolling rolls working layer of plate mills finishing stands. During the operation of new rolls experimental batches, it was established that their productivity is $12-14 \%$ higher than the performance of the used rolls.

\section{References}

1. Pritomanova M.I., Vyshinskaya L.R. The effect of silicon on volume changes in thermal cycling of graphitized alloys. Struktura $i$ svoystva chuguna $i$ stali. Nauchnyye trudy [Structure and properties of cast iron and steel. Research papers]. Vol. 26. Ed. by K.P. Bunin. Moscow: Metallurgiya, 1967 , pp. 159-168.

2. Spravochnik po chugunnomu lityu [Handbook in iron casting]. Ed. by N.G. Girshovich. 3rd ed. Leningrad: Mashinostroenie, 1978, $758 \mathrm{p}$.

3. Gimaletdinov R.Kh., Gulakov A.A., Tukhvatulin I.Kh. Influence of chemical composition on the properties of the working layer of centrifugal cast indefinite chill rolls. Vestnik Magnitogorskogo gosudarstvennogo tehnicheskogo universiteta im. G.I. Nosova [Vestnik of Nosov Magnitogorsk State Technical University], 2016, vol. 14, no. 3, pp. 78-89.

4. Belov V.D., Vdovin K.N., Kolokoltsev V.M., Kovalevich E.V., Ten E.B., Ri Khosen, Ri E.Kh. Proizvodstvo chugunnykh otlivok [Production of iron castings]. Ed. by V.M. Kolokoltsev and Ri Khosen. 2nd ed. Magnitogorsk: Publishing House of Nosov Magnitogorsk State Technical University, 2011, $521 \mathrm{p}$.

5. Popov V.S., Vasilenko G.I., Nagornyy P.L. Abrasive wear of some high-carbon alloys. Metallovedenie $i$ termicheskaya obrabotka metallov [Physical metallurgy and heat treatment of metals], 1970, no. 5, pp. 47-48.

6. Freeman R. B. The Relative Wear of Some Hard Metals. Metal Progress, 1937, vol. 31, pp. 281-284.

7. Hirsch W. F. Nickel-Boron Cast Iron for Resistance to Abrasion. Metal Progress, 1938, vol. 34, pp. 230-232.

8. Bor, kaltsiy, niobiy i tsirkoniy v chugune $i$ stali [Boron, calcium, niobium and zirconium in iron and steel]. Translated from English by V.A. Mchedlishvili and V.V. Khovrin. Ed. by S.M. Vinarov. Moscow: GNTI ChTsM, 1961, 460 p.

\title{
ВЛИЯНИЕ ХИМИЧЕСКОГО СОСТАВА НА ПРОИЗВОДИТЕЛЬНОСТЬ ЦЕНТРОБЕЖНО- ЛИТЫХ ИНДЕФИНИТНЫХ ПРОКАТНЫХ ВАЛКОВ
}

\author{
Гималетдинов Р.Х., Гулаков А.А., Тухватулин И.Х.
}

ЗАО «КЗПВ», Кушва, Россия

\begin{abstract}
Аннотация. Постановка задачи (актуальность работы). Актуальной задачей для прокатчиков является минимизация затрат на выпускаемую продукцию при условии обеспечения требуемого качества. Для ее решения осуществляются мероприятия по усовер-
\end{abstract}

шенствованию технологического процесса прокатки, направленные на увеличение длительности кампаний и уменьшение количества переточек валков. На производительность прокатных валков влияют свойства материала рабочего слоя валков, определяющие со- 


\section{ЛИТЕЙНОЕ ПРОИЗВОДСТВО}

противление износу, образованию и развитию сетки разгара, устойчивость к налипанию металла. Листопрокатные валки чистовых клетей определяют качество поверхности листового проката, поэтому важно своевременно производить переточки для полного удаления слоя с сеткой разгара. Глубина съема и приемлемая длительность кампаний зависят от свойств материала рабочего слоя валков. Для улучшения свойств прокатных валков изготовителям валков важно иметь информацию о результатах эксплуатации валков в станах, позволяющую провести анализ влияния химического состава и структуры рабочего слоя валков на их производительность. Проведение такого анализа позволит улучшить структуру и свойства применяемых материалов и разработать новые. Цель работы. Исследование влияния химического состава рабочего слоя индефинитных листопрокатных валков чистовых клетей на производительность (наработку) валков, оценка эффективности влияния каждого химического элемента и определение интервалов содержания химических элементов, наиболее эффективно повышающих производительность индефинитных листопрокатных валков. Используемые методы. Создание базы данных по наработке индефинитных листопрокатных валков чистовых клетей, искусственные нейронные сети на основе алгоритма двойственного функционирования. Новизна. Получена нейромодель, позволяющая изучить влияние химического состава рабочего слоя и прогнозировать производительность индефинитных валков. Исследовано влияние углерода, кремния, марганца, хрома, никеля, молибдена, ванадия, ниобия и бора на производительность индефинитных валков. Результаты. Построены графические диаграммы влияния каждого химического элемента на производительность индефинитных валков при постоянных концентрациях остальных элементов. Рассмотрено влияние химических элементов на производительность с точки зрения воздействия их на структуру индефинитного чугуна. Определены эффективные интервалы содержания химических элементов. Практическая значимость. Разработан новый химический состав индефинитного чугуна для рабочего слоя прокатных валков чистовых клетей листопрокатных станов, достигнуто повышение производительности валков на $12-14 \%$.

Ключевые слова: прокатные валки, индефинитный чугун, химический состав, влияние, производительность, износостойкость.

Gimaletdinov R.Kh., Gulakov A.A., Tukhvatulin I.Kh. Effect of chemical composition on the performance of centrifugally cast indefinite chilled cast iron rolls // Вестник Магнитогорского государственного технического университета им. Г.И. Носова. 2019. Т.17. №1. С. 32-36. https://doi.org/10.18503/1995-2732-2019-17-1-32-36

For citation

Gimaletdinov R.Kh., Gulakov A.A., Tukhvatulin I.Kh. Effect of chemical composition on the performance of centrifugally cast indefinite chilled cast iron rolls. Vestnik Magnitogorskogo Gosudarstvennogo Tekhnicheskogo Universiteta im. G.I. Nosova [Vestnik of Nosov Magnitogorsk State Technical University]. 2019, vol. 17, no. 1, pp. 32-36. https://doi.org/10.18503/1995-2732-2019-17-1-32-36 